The Next Generation of Biomarker Research in Spinal Cord Injury Peer-reviewed author version

YDENS, Elke; PALMERS, Ilse; HENDRIX, Sven \& SOMERS, Veerle (2017) The Next Generation of Biomarker Research in Spinal Cord Injury. In: Molecular neurobiology, 54 (2), p. 1482-1499.

DOI: $10.1007 / \mathrm{s} 12035-016-9757-\mathrm{x}$

Handle: http://hdl.handle.net/1942/23294 


\section{The next generation of biomarker research in spinal cord injury}

Elke Ydens ${ }^{1, *}$, Ilse Palmers ${ }^{1, *}$, Sven Hendrix ${ }^{1}$ and Veerle Somers ${ }^{1, \#}$

${ }^{1}$ Hasselt University, Biomedical Research Institute and Transnationale Universiteit Limburg, School of Life Sciences, Diepenbeek, Belgium

${ }^{*}$ Contributed equally to this work

${ }^{\#}$ Corresponding author:

Prof. dr. Veerle Somers

Hasselt University

Martelarenlaan 42

3500 Hasselt, Belgium

Tel: 003211269202

Email: veerle.somers@uhasselt.be

\section{Keywords}

Antibody, biomarker, patient, serum

\section{Acknowledgements}

This study is supported by Research Foundation Flanders (FWO Vlaanderen), Hasselt University and the Transnationale Universiteit Limburg. I. Palmers is supported by a doctoral fellowship of the Agency for Innovation by Science and Technology (IWT).

\section{Conflict of interest}

The authors declare that they have no conflict of interest. 


\begin{abstract}
In traumatic spinal cord injury (SCI) patients, the assessment of the exact degree of lesion severity and neurological prognosis has proven to be extremely challenging. The current tools for predicting functional outcome in SCI patients such as clinical examination and magnetic resonance imaging are often inaccessible to unstable or polytraumatized patients, lack sensitivity and are unreliable in the acute phase of the injury. Multiple candidate protein biomarkers known to be linked to the pathology have been studied for their potential to predict neurological outcome over time. This hypothesis-driven approach however, has yielded only minimal success and the reported individual markers lack sensitivity and correlation with specific outcome measures, which highlights the need for an unbiased highthroughput screening approach to identify novel candidate biomarkers. Antibodies were suggested to represent better biomarkers as their counterpart antigens as they are highly specific and abundantly present in blood due to their inherent amplification and long half-life. Moreover, antibodies are easily accessible, and are amenable to high-throughput screening. We therefore suggest an unbiased, high-throughput and powerful antibody profiling procedure, named Serological antigen selection, based on cDNA phage display to combine the multiple benefits of stable and frequent antibodies and those of an unbiased method. The application of such an innovative and unbiased approach can complement the more traditional approaches to aid in the discovery of novel SCI-associated biomarkers.
\end{abstract}




\section{Introduction}

A spinal cord injury (SCI) is a physically devastating condition that often results in lifelong functional disability. SCI comprises a very heterogeneous patient population, which is caused by differences in injury pattern, severity, location, genetic background, pre-injury health situation, and variability in medical, surgical and rehabilitative care. Currently, SCI is diagnosed based on neurological symptoms and imaging of the spinal cord. Magnetic resonance imaging (MRI) is currently considered the best imaging technique for evaluating traumatic SCI during the acute phase [1]. Standard clinical MRI sequences effectively identify spinal cord compression, transection, edema, and hemorrhage.

While the diagnosis of acute traumatic SCI is usually quite straightforward, the identification of the precise degree of severity and the prognosis of neurologic outcome have proven to be more challenging. Currently, neurological examination according to the American Spinal Injury Association (ASIA) impairment scale (AIS) is the most predictive tool to assess functional outcome, especially when combined with MRI findings [2-4]. The AIS scores are considered to be reliable and prognostic in SCI patients when assessed 72 hours after the initial trauma [5,6]. However, within the first 72 hours, several factors such as spinal shock, concomitant brain injury, coma or sedation may affect the reliability of this neurological examination [5]. Moreover, clinical examination is not always feasible and reliable in patients with unstable early clinical status and other systemic injuries.

The current classification system to stratify SCI patients, which is based on the AIS scores, artificially reduces the variability of the heterogeneous SCI patient population [7]. Patients with the same AIS score are classified in the same group in clinical studies, however, these patients might be very distinct with respect to other aspects such as the level and extent of injury and recovery potential. As a consequence, the probability of finding any correlation between the neurological status of patients and the functional outcome is diminished and the 
effects that might be present in some patients are masked by the extensive variation within the groups. Due to this suboptimal stratification of patients and variability in spontaneous recovery, the number of participants needed to have sufficient statistical power to detect clinically important differences in function becomes unrealistically high.

MRI is a second tool for assessing a patient's recovery potential as MRI findings such as parenchymal hemorrhage, transection, and longer lesion length were shown to correlate with less favorable neurological outcomes [4]. The conventional MRI sequences, however, do not provide in depth information about the integrity of critical long white matter tracts which are responsible for the observed functional deficits after SCI [8,9]. In addition, MRI is often unavailable in many locations and even when available, patients with multiple injuries may be too unstable and inaccessible for early MRI.

Altogether, neurological examination and MRI are not always accessible, feasible and reliable in unstable SCI patients. Moreover, the outcome measures that are traditionally used are insufficiently sensitive to predict recovery over time. These pitfalls of the current tools for predicting functional outcome in SCI patients highlight the need for more accurate means to define injury severity and better predict neurological outcome and for more sensitive outcome measures that can identify small changes in neurological function to assess recovery. In the case of SCI, an objective and quantifiable method such as the assessment of biomarkers in biofluids, might significantly aid in the evaluation of the extent of traumatic injury, particularly in the early phase of the injury to more accurately predict how the patient will progress. The increased extent of injury, which is often classified by the same AIS score, may be reflected in the different concentration of biomarkers. Additionally, biomarkers are an efficient way to measure the progression of the injury over time. A better characterization of SCI patients using biomarkers will ultimately result in a more suitable disease management. Moreover, biomarkers could be used as an approach to triage individual SCI patients for more 
costly examination as well as to stratify patients included in clinical trials in more relevant groups according to the design and desired outcome. The evaluation of the efficacy of novel therapies for SCI in clinical trials may also be done in a more sensitive manner by using biomarkers. Biomarker research for SCI would, furthermore, significantly contribute to the elucidation of SCI pathophysiological mechanisms and thereby hint to new therapeutic options. In this review we shortly discuss the current candidate SCI biomarkers, however, we mainly focus on strategies to boost the use of the current potential biomarkers and approaches to identify novel biomarkers. An overview of the discussed strategies for biomarker discovery and their strengths and weaknesses is given in Figure 1 (lower panel).

\section{Biomarkers in SCI}

According to the Biomarkers Definitions Working Group, a biomarker is defined as 'a characteristic that is objectively measured and evaluated as an indicator of normal biological processes, pathogenic processes or pharmacological responses to a therapeutic intervention'.

Trauma to the spinal cord results in an acute physical injury, and leads to axonal damage and neuronal necrosis (Figure 1a). This primary neuronal destruction may cause leakage of cellular proteins and breakdown products into the cerebrospinal fluid (CSF) and subsequently into the bloodstream (Figure 1b). Also the glial membranes are damaged, triggering glialspecific protein release into biofluids. In the secondary phase, an injury-triggered inflammatory response results in elevated levels of inflammatory mediators such as cytokines and chemokines (Figure 1c). The amplified inflammatory response can persist months to years after the initial injury (Figure 1d) and may contribute to the expansion of the initial lesion (Figure 1e). Starting from these key processes, the search for SCI-specific biomarkers has been approached in two ways; 1) by analyzing structural proteins that are abundant in the spinal cord and that might be released from damaged nervous tissue during the primary phase, and 2) by measuring components of the inflammatory response in the secondary phase [10]. 
The biomarkers identified via these hypothesis-driven approaches have been extensively reviewed by others [11-13] and are only shortly discussed below, where we focus mainly on the data from recent human studies.

\section{Structural and functional biomarkers}

In central nervous system (CNS) diseases, mainly structural proteins that maintain cell shape and compose structural elements of neurons and glia have been studied for their biomarker potential as they may reflect the degree of injury. Likewise, functional proteins with CNS-specific biological activity have also been addressed in SCI biomarker research.

Neuron-derived proteins such as neuron specific enolase (NSE), tau and neurofilaments (NFs) have been of considerable interest to be evaluated in serum and CSF as SCI biomarkers (Table 1). Glial proteins may also be used as biomarkers of SCI, reflecting the injury of the glial population residing in the spinal cord. Therefore, oligodendrocyte- and astrocyteassociated proteins such as S100B, glial fibrillary acidic protein (GFAP) and myelin basic protein (MBP) have been investigated as potential SCI biomarkers (Table 1).

\section{Neuron-derived biomarkers}

NSE is a subunit of the glycolytic enzyme enolase and is localized predominantly in the cytoplasm of neurons. Upregulated NSE is released from damaged neurons to maintain homeostasis [14]. While animal models highlighted promising features for NSE as a SCI biomarker [15-17], studies in humans have only recently addressed the NSE biomarker potential. The levels of NSE within CSF in a cohort of 16 SCI patients were increased and correlated with the baseline neurologic impairment being either motor complete (AIS A and B) or motor incomplete (AIS C and D) [18]. Ahadi et al. (2015) recently found that also serum NSE levels were significantly higher during the first 48 hours after injury in the 26 traumatic SCI patients included in the study compared to the control group [19]. In a 
population of 34 patients with vertebral spine fractures, however, the analysis of NSE levels revealed no significant difference [20].

Tau is a microtubule-binding phosphoprotein that is highly enriched in axons. Data on the use of tau as a biomarker for traumatic brain injury (TBI) is inconsistent (reviewed by [21]). Measurement of tau in CSF of 27 patients with complete (AIS A; n=14) and incomplete (AIS $\mathrm{B}$ and $\mathrm{C} ; \mathrm{n}=13$ ) SCI showed that tau levels were elevated in a severity-dependent manner [22]. On the other hand, tau levels were not increased in the 3 patients with postoperative spinal cord ischemia and paraparesis compared to the group of 20 patients without neurological complications [23].

Another class of neuronal proteins that has been addressed as biomarkers in SCI are NFs. These major cytoskeletal components are expressed in axons and the NF-polymer consists of light, medium and heavy chains. After injury, the phosphorylation state of NFs is altered, which leads to the local loss of cytoskeleton integrity [24]. In SCI patients, phosphoneurofilament heavy (pNF-H) levels in blood became detectable already $12 \mathrm{~h}$ after injury and remained elevated at day 21 post-injury [19,25]. The increase in pNF-H plasma levels of 14 SCI patients was more pronounced in the patients with complete compared to the patients with incomplete SCI and might reflect a greater magnitude of axonal damage [25]. Another study that included 16 SCI patients reported that also CSF levels of unphosphorylated NF-H were significantly increased in motor complete patients versus motor incomplete patients [18]. Furthermore, neurofilament light (NF-L) levels were shown to be elevated in CSF of SCI patients [26,27]. Recently, Kuhle et al. (2015) found that serum NF-L levels increased over time and that the levels correlated with the AIS scores at baseline and after $24 \mathrm{~h}$ and with motor outcome several months after the injury based on NF-L screening in 13 motor complete, 10 motor incomplete and 67 healthy controls [26]. NFs might thus have prognostic value in SCI patients. 


\section{Glial-derived biomarkers}

$\mathrm{S} 100 \mathrm{~B}$ is a dimeric calcium-binding protein localized predominantly in astroglial and Schwann cells and is the most intensively studied marker in SCI. Both serum and CSF levels of S100B are elevated in SCI patients $[22,20,18,28]$. The concentration of S100B was significantly higher in patients with a motor complete injury compared to patients with motor incomplete injury $[18,22]$. Furthermore, in 12 patients with vertebral fractures which showed neurologic deficits, S100B levels were higher compared to the 22 patients without neurological deficits [20]. In patients with spinal cord compression resulting from epidural empyema $(n=34)$ or metastases $(n=11)$, normal or transiently increased S100B levels were associated with a beneficial outcome, whereas persistently elevated S100B levels were related to a lower extremity muscle power outcome $[29,30]$. The same trend was seen in complicated courses of postoperative deterioration in a cohort of 51 patients with spondylotic cervical myelopathy, in which a single subject that showed major functional decline had persistently elevated S100B levels while the 2 patients that recovered after neurological decline showed no or a transient increase in S100B levels [31]. S100B levels might thus have prognostic relevance in several SCI pathologies.

A second glial protein that has been addressed in SCI biomarker research is GFAP, which is exclusively found in the CNS and is a part of the astroglial skeleton. While CSF levels of GFAP have been found to be increased in a severity-dependent fashion in SCI patients by several studies [22,27], elevated serum levels of GFAP were only recently reported [19]. The serum level of GFAP was useful for estimating SCI severity within the first 24 hours after injury in a cohort of 26 SCI patients [19].

Lastly, MBP is one of the most abundant proteins in the white matter and is a major constituent of the myelin sheath. This protein was studied in a SCI animal model, where the concentrations of MBP significantly increased in serum and CSF already 3 hours after injury 
[32]. In humans, a single study retrospectively identified higher concentrations of MBP in

CSF of patients with tropical spastic paraparesis compared to CSF of patients with nonneurological diseases [33].

\section{New structural SCI biomarkers based on data from CNS injury and neurological} disorders

As several processes in SCI and TBI are believed to be similar in both pathologies, many of the structural proteins that are currently being investigated as markers for SCI were originally studied in TBI (recently reviewed by [10,21]). By carefully analyzing the presence of protein biomarkers in other neurological disorders and CNS injuries such as TBI, Yokobori et al. (2013) suggested a role for ubiquitin carboxy-terminal hydrolase L1 (UCH-L1) and $\alpha$-II spectrin breakdown products (SBDPs) as putative biomarkers for SCI (Table 1) [13].

$\mathrm{UCH}-\mathrm{L} 1$ expression is highly specific to neurons and this protein is abundantly present in all neurons. Mutations in the gene encoding UCH-L1 have been associated with familial Parkinson's disease [34]. Furthermore, Zeterberg et al. found that polymorphisms of this gene are linked to Alzheimer's disease [35]. By differential neuroproteomic analysis of TBI in rats, UCH-L1 was suggested as a biomarker for severe TBI [36]. In TBI patients, CSF levels of UCH-L1 were significantly elevated compared to uninjured controls and increased levels were associated with measures of injury severity, complications and outcome [37]. Similarly, serum levels of UCH-L1 correlated to injury severity and survival outcome in TBI [38]. Interestingly, UCH-L1 levels are also elevated in spinal cord tissue 5 days after injury [39].

Intact $\alpha$-II spectrin is a structural component of axolemmal cytoskeleton abundant in axons and presynaptic terminals. This protein is a major substrate for proteases involved in necrotic (calpain-I) and apoptotic cell death (caspase-3). It is cleaved into SBDPs of 150kDa and $145 \mathrm{kDa}$ by calpain-I or $120 \mathrm{kDa}$ and $150 \mathrm{kDa}$ by caspase- 3 , and thus these SBDPs can be used to detect necrosis and apoptosis, respectively. In a rat model of TBI, SBDP levels 
correlated with injury severity, lesion size and behavioral deficit [40] and in patients with severe TBI, SBDPs are considered potential biomarkers for brain trauma [41-45]. SBDPs have also been found in a model of SCI, and were detected already 15 minutes after the injury, suggesting that these breakdown products can potentially be used as an early biomarker for neuronal injury [46,47].

Yokobori et al. (2013) further addressed the use of UCH-L1 and SBDP as putative biomarkers for SCI by measuring their concentrations in serum and CSF in a weight-drop SCI rat model and in SCI patients. Both UCH-L1 and SBDPs levels were elevated in CSF as early as $4 \mathrm{~h}$ after SCI in rats and were found in serum and CSF in a SCI patient 2 days after injury (the earliest time point investigated) [13]. Besides SBDP, also GFAP breakdown products might represent new candidates for biomarker research (Table 1). The concept is that these breakdown products are readily released upon brain injury while full-length GFAP is released to a lesser extent [48]. An advantage of GFAP as a brain biomarker is that it shows strong brain specificity and high expression levels in the brain. In TBI, the diagnostic value of GFAP breakdown products showed clear promise in patients [49-51]. GFAP breakdown products were already found in rat CSF as well as in a SCI patient [13].

Altogether, the functional proteins NSE and S100B have been found to be more increased in patients with complete injury compared to patients with incomplete injury, yet as both proteins can also be found in red blood cells and platelets [52], their diagnostic utility as a SCI-specific marker can be questioned, especially in polytraumatized patients. On the other hand, structural biomarkers such as tau, NFs and GFAP are increased in serum and CSF in a severity-dependent fashion. Although extensive validation of these markers is still needed, they emerge as promising candidate biomarkers for the estimation of injury severity. These data encourage the evaluation of known and new structural biomarkers for injury severity in SCI pathology. 


\section{Inflammatory biomarkers}

Inflammation is considered to play a central role in the pathophysiology of secondary injury after SCI. Moreover, it is almost certain that therapeutic strategies for acute SCI will influence or be influenced by the inflammatory response, which makes the investigation of inflammatory mediators highly essential. Animal models, in which the lesion severity to the spinal cord was precisely controlled, have demonstrated that concentrations of inflammatory mediators such as interleukin (IL)-1 $\beta$, IL-6 and tumor necrosis factor (TNF) after injury are 'titrated' according to the severity of the neurologic deficit [53]. This aspect further justifies the evaluation of inflammatory mediators as potential biomarkers of injury severity.

\section{Blood-derived versus CSF-derived inflammatory biomarkers}

Ideally, peripheral biomarkers are measured in an easy accessible biofluid such as blood (serum and plasma). Blood is easily processed, provides relatively homogenous samples, and there is a large amount of normative data available [54]. Analysis of blood samples can also present difficulties such as deciphering the origin of proteins as blood comes in contact with all tissues and organs. Moreover, issues regarding the sensitivity and dynamic range have been reported for protein biomarkers in blood [55]. CSF samples might be more relevant for SCI biomarker discovery, however, collecting CSF samples is much more invasive and not always feasible from patients that suffered multiple trauma or that are unstable.

Especially when addressing cytokine levels as potential SCI biomarkers, one has to carefully consider which biofluid to use. It was shown that the increased IL-1 $\beta$ levels within the spinal cord were comparable to the levels within the CSF. However, the systemic (serum) levels of this cytokine were much lower and did not correlate with those in the injured spinal cord [56]. A similar phenomenon was observed analyzing TNF levels, with levels measured in the CSF correlating closely with those in the spinal cord, but not with those in serum [57]. 
Similarly, in SCI patients, serum concentrations of the inflammatory mediators were often found to be substantially lower than CSF concentrations taken at the same time [22].

\section{Inflammatory biomarkers in CSF}

In CSF samples of SCI patients, a plethora of inflammatory mediators have been investigated. Pro-inflammatory cytokines (e.g. IL-1 $\beta$, IL-6, IL-8, IL-16, TNF), chemokines (e.g. C-X-C motif chemokine (CXCL)-10, monocyte chemoattractant protein (MCP)-1 and neutrophil attractant protein (NAP)-2), as well as growth factors (e.g. nerve growth factor (NGF)) have been found to be increased in CSF of SCI patients compared to controls (Table 2) $[58,22,59]$. Despite the detection of a broad range of inflammatory mediators in CSF of SCI patients, the majority of cytokines (including TNF and IL-1 $)$ ) and growth factors were not measurable when using a multiplex kit [22].

In addition, levels of enzymatic proteins (e.g. heme oxygenase (HO)-1 and matrix metalloproteinase (MMP)-2 and MMP-9) and their inhibitors (e.g. tissue inhibitors of metalloproteinase (TIMP) 1) that control the ongoing inflammatory response are elevated in SCI patients $[58,59]$. The CSF levels of several of these inflammatory proteins (IL-6, IL-8 and MCP-1) were even elevated in a severity-dependent fashion in a cohort of 27 acute SCI patients [22] and cumulative concentrations of IL-1 $\beta$, MMP-9 and CXCL-10 showed a statistically significant correlation with injury severity [59].

Eicosanoids are important signaling molecules in controlling vascular permeability and have a role in secondary processes mediating ischemia and edema in SCI. The eicosanoids leukotriene C4 (LTC4), thromboxane B2 (TXB2), and 6-keto-prostaglandin F1a (6-ketoPGF1a) were increased in CSF of SCI patients as compared to controls. The levels of LTC4 were specifically and significantly increased in the 6 patients with complete as compared to 5 patients with incomplete paralysis. Concentrations of the other investigated leukotrienes in 
this cohort also showed a trend to higher levels in complete SCI patients, but this increase was not statistically significant [60].

\section{Inflammatory biomarkers in blood-derivatives}

SCI subjects exhibited serum concentrations of a considerable amount of proinflammatory cytokines (colony-stimulation factor (CSF)-1, IL-2, IL-2R, IL-3, IL-6, IL-9, IL16, IL-18 and TNF) that were greater than in controls (Table 2) [61-67]. In contrast to several other studies, Frost et al. (2005) did not observe elevated levels of IL-6 and TNF in 37 subject with chronic SCI $[61,67,65,66]$. In addition to a pro-inflammatory cytokine profile, the levels of the anti-inflammatory cytokine IL-10 and the IL-1 receptor antagonist (IL-1RA) are increased in SCI patients $[61,68]$. When comparing 21 SCI patients to 21 trauma patients without neurological damage, especially circulating levels of IL-10 were significantly increased in SCI compared to non-SCI patients, whereas the levels of several proinflammatory cytokines (IL-1 $\beta$, sIL-2R $\alpha$, IL-4, IL-5, IL-7, IL-13, IL-17, and interferon (IFN)$\gamma$ ) and chemokines (macrophage inflammatory protein (MIP)-1 $\alpha$ and $-1 \beta$ and granulocyte macrophage colony stimulation factor (GM-CSF)) were significantly reduced [68]. The elevated levels of IL-10, however, were not found in an earlier study in which 24 SCI patients were compared to healthy controls [62]. Recently, IL-10 levels were found to be significantly lower than the level at admission, unfortunately, control subjects were not included [63].

Additionally, increased serum level of chemokines (CCL4, MCP-1, macrophage migration inhibitory factor (MIF), CXCL-1, CXCL-9, CXCL-10 and CXCL-12) were evident in SCI patients $[64,65,69,70]$. The levels of CXCL-1, CXCL-9 and CXCL-10 reached a peak on day 7 after SCI and then declined to control level. In contrast, the increased expression of CXCL-12 was persistent up to 28 days after SCI [70]. Furthermore, increased levels of growth factors (stem cell growth factor beta (SCGF $\beta$ ) and hepatocyte growth factor (HGF)), 
acute phase protein ( $\mathrm{C}$-reactive protein) and the adhesion molecule (intercellular adhesion molecule (ICAM-1)) have been reported in serum of SCI patients $[66,67,65,64]$.

In most studies that assessed correlations between serum levels of inflammatory mediators and clinical parameters (level of injury or AIS classification), no association could be found $[61,64]$. Still, levels of IL-6 and IL-1RA did show a further increase in subjects with pain, urinary tract infection and pressure ulcers compared to SCI subjects who were asymptomatic for medical complications [61]. SCI patients with high plasma levels of CXCL10 had significant prolonged stay in the hospital and a worse respiratory function [68]. Moreover, by evaluating the levels of TNF in SCI patients with and without neuropathic pain, the authors showed that TNF could be a potential sensitive diagnostic biomarker for chronic neuropathic pain in SCI patients [71]. Recently, Moghaddam et al. (2015) analyzed the complete temporal profile (from 4 hours to 12 weeks after SCI) of 7 different cytokines and growth factors and compared serum levels between patients with neurological improvement to those without improvement [63]. TNF, IL-1 $\beta$, IL-6, IL-8 and IL-10 levels were all higher in patients without neurological remission and in patients with an initial AIS A. While still many discrepancies exist, several inflammatory mediators do show potential as a SCI biomarker (Table 2).

\section{Antibodies as a novel source of potential SCI biomarkers}

Within the circulation, also antibodies are present. Besides the production of antibodies against foreign molecules, the immune system generates antibodies to self-proteins in response to many pathological processes. It is believed that these antibodies are generated against overexpressed, mutated or misfolded proteins, against aberrantly degraded or glycosylated proteins or against proteins released from damaged tissues. Since after traumatic SCI, the blood-spinal cord barrier is compromised, spinal cord specific proteins can be released into the periphery and trigger an immune response, including the development of 
antibodies. In an animal model, SCI induced a strong increase of circulating pathogenic antibodies and antibodies against brain proteins have already been implicated in a variety of neurological disorders such as stroke, multiple sclerosis, epilepsy and Alzheimer's disease. In SCI, Yokobori et al. (2013) found GFAP and its breakdown products in CSF of a SCI patient. Interestingly, this patient had also developed an antibody response against GFAP and the breakdown products starting from day 6 after injury [13]. These results highlight that antibody reactivity against self-proteins can develop upon SCI in humans, once these proteins are 'secreted' from the CNS. Furthermore, antibodies against gangliosides, MBP, myelin associated glycoprotein, myelin proteolipid protein and against nuclear antigens have been found after SCI $[61,62,72-75]$. Elevated titers of antibodies against several myelin proteins were found in sera of SCI patients until years after the initial injury, showing that antibodies are prolonged present in the blood of SCI patients. Interestingly, correlations between the presence of these antibodies and clinical parameters (e.g. SCI complications) were found by several independent studies $[75,61,62,73]$.

In conclusion, while serum-derived inflammatory mediators do not seem to correlate with level of injury or AIS classification, inflammatory mediators in CSF do show association with injury severity. Furthermore, data on serum-derived inflammatory candidate biomarkers is inconsistent, probably due to the lower cytokine levels and multiple sources of cytokine production, especially in polytraumatized patients. CSF thus seems to be the biofluid of choice to evaluate injury severity based on inflammatory biomarkers. Still, inflammatory markers in serum might be useful for the assessment of SCI-associated medical complications such as pain, infections and pressure ulcers and to selectively adapt patient care to those at high risk. Moreover, antibodies in serum represent interesting new candidates for biomarker discovery in SCI pathology. 


\section{Biochemical modelling of biomarkers}

Even though elevated concentrations of potential biomarkers have been identified in patients with SCI, the current candidate biomarkers do not yet provide a sensitive diagnostic or prognostic tool. Main issues that none of the biomarkers can be efficiently used as an individual marker for SCI involve the sensitivity of the candidate biomarkers, the lack of correlation with certain outcome measures and the heterogeneity of the SCI population. It is likely that for a complex condition such as SCI, a single biomarker will not reflect the full spectrum of the response of the injury. A strategy to attain an improved sensitivity and specificity for the characterization of the injury severity involves the biochemical modelling of biomarkers, thereby combining different markers into a biomarker panel that is more specific for certain outcome measures (Figure 1, lower panel) $[13,76]$.

Kwon et al. (2010) used the CSF concentrations of a combination of both putative structural and inflammatory biomarkers, namely S100B, GFAP and IL-8, to classify the injury severity of SCI patients. This study was able to predict the AIS grade with an accuracy of 89\% using these CSF biomarkers [22]. The panel of biomarkers could even predict motor outcome at 6 months better than the standard clinical AIS classification. More studies that model biomarkers into panels are highly required to fully characterize a specific SCI fingerprint that can be of great use from a clinical point of view.

\section{Towards an unbiased approach}

While combining biomarkers into a panel is a reliable and powerful strategy, up till now, there is only a limited number of candidate biomarkers available. Most studies described above use a hypothesis-driven approach, in which biofluids are screened for biomarkers that are known to be associated with SCI pathology, that have a high expression in the spinal cord or that have been linked to a similar pathology such as TBI. As a consequence, SCI biomarker 
research has largely been biased towards the investigation of structural and inflammatory biomarkers. This approach yielded only limited success in identifying markers that can be used clinically and there is a strong need for the identification of additional candidate biomarkers. The heterogeneous nature of the SCI population further underscores the importance of a unbiased, high-throughput approach to identify the full spectrum of potential SCI biomarkers. With the innovation of high-throughput detection methods, such as multiplex analysis, metabolomics, proteomics and genomics, the field of biomarker research has progressed rapidly in many disease entities. Unfortunately, in SCI research, studies using the 'omics' approach are limited.

\section{Proteomics approach to identify putative biomarkers for SCI}

Proteomics is used to comprehend the relationship between different proteins and how they change by disease to understand human pathophysiology, and ultimately to provide new therapeutic options and clinical tools. There are several limitations to the use of proteomic techniques such as the low sensitivity of 2D gel electrophoresis towards integral membrane proteins and the possible display of artifacts and protein degeneration due to sample collection and storage $[55,77,78]$. Still, high-throughput proteomics has emerged as an invaluable tool in the quest to unravel the biochemical changes and is a powerful approach to identify novel biomarkers for SCI. Several studies have applied a proteomic approach on spinal cord tissue

of animals at time points ranging from 8 hours to 5 days after injury [79-81,39,82-84]. Combined, these studies identified approximately 170 unique proteins that were differentially changed in abundance or that were subjected to distinct post-translational modifications after SCI. Whether the proteins identified in these studies are truly useful as SCI biomarkers awaits further investigation.

By performing a proteomic analysis of CSF from rats 24 hours after SCI, Lubieniecka et al. (2011) identified 42 putative biomarkers for traumatic SCI that showed at least a 2-fold 
difference in abundance compared to CSF from an uninjured spinal cord [85]. Additionally, as both a moderate and severe injury model was included in the study, they could determine 10 proteins that were differentially changed depending on the injury severity and that might represent potential biomarkers of SCI severity. The identified proteins are involved in various processes such as the acute phase response (inter-alpha-inhibitor H4 heavy chain (ITIH4), alpha-1-acid glycoprotein (ORM1)), inflammation (protein S100-A8 (S100A8), peroxiredoxin-2 (PRDX2), RGD1564861), metabolic processes (glutathione peroxidase 3 (GPX3), carbonic anhydrase 1 (CAR1), CAR2), oxygen transport (zero beta-1 globin (MGC72973)) and pregnancy (pregnancy zone protein (PZP)). Further bioinformatics analysis of the proteins modulated after SCI (1,5-fold change) identified an abundant number of molecular and cellular processes that were significantly affected in both injury severities. Still, proteins involved in cell morphology, cell signaling, antigen presentation, molecular transport and vitamin and mineral metabolism were associated with moderate injury, whereas, processes such as cellular movement, development, macromolecular assembly, cellular organization, cell death, small molecule biochemistry and amino acid and lipid metabolism were more apparent in severe SCI [85]. A second study employed multiplex analysis of inflammatory mediators in CSF and demonstrated significant increases in MMP-8 protein after traumatic injury to the spinal cord. The authors concluded that MMP-8 might represent a novel subacute-phase CSF biomarker for SCI [86].

To our knowledge, only 1 study investigated CSF biomarkers in SCI patients using proteomics. Sengupta et al. (2014) compared CSF of SCI patients with either complete injury (AIS A) or incomplete injury (AIS B or C) at an early time point (1-8 days post-injury). The set of identified proteins did not differ between the two severity groups, however, the abundance of 8 proteins was clearly affected by injury severity [87]. These proteins include haptoglobin (Hp), zinc-alpha-2-glycoprotein (AZGP1), transferrin (TF), apolipoprotein 
(APO) $\mathrm{H}$, general transcription factor $3 \mathrm{C}$ polypeptide 5 (GTF3C5), serum albumin precursor (ALBU), Ig gamma-2 chain C region (IGHG) 2 and IGHG4. The abundance of these severitydependent proteins in CSF was also analyzed at a later time point after injury (15 to 60 days). Some proteins such as Hp and AZGP1 which were initially enriched in incomplete injury, showed a reversal in their abundance profile. On the other hand, APOH and GTF3C5 exhibited an opposite regulation, being present more pronounced in complete injury at the early time point but not at the later time point. The remaining proteins were all increased in complete injury compared to incomplete injury at both time points investigated [87].

Interestingly, several proteins, such as PRDX2, alpha-1-microglobulin/bikunin precursor (AMBP), APOA1, APOH, serpin peptidase inhibitore, clade C, member 1 (SERPINC1), that were identified in rat CSF were also found increased in CSF of SCI patients. Moreover, overlap is seen in the set of proteins identified in spinal cord tissue and CSF of rats and humans. Accordingly, data from spinal cord tissue proteomic studies are valuable for SCI biomarker discovery, provided that the findings are further checked and validated in biofluids of SCI patients. Still, studies that begin their proteomic screens in biofluids of SCI subjects are more likely to be successful in the identification of novel SCI biomarkers.

\section{Phage display and serological antigen selection}

An innovative and unbiased strategy for the detection of biomarkers is the application of the phage display technique. This highly promising approach is based on the potential of a filamentous phage particle to incorporate foreign DNA into its genome coupled to a gene encoding a phage coat protein and the subsequent display of the corresponding DNA product on the phage surface. The strength of this technique lies within the physical link between genotype and phenotype, which enables the succession of affinity selection and amplification of the selected phage particles resulting in powerful enrichment of selected phage. This technique, furthermore, circumvents issues related to the gel-based high-throughput 
techniques. One of the most disease-relevant systems is created by the incorporation of the entire cDNA sequence of the target tissue in the phage genome, so that the phage cDNA display library is fully representative for the heterogeneity present within the in vivo target tissue. Applying this approach furthermore allows the identification of unknown or uncharacterized sequences expressed within the cDNA library. Phage display is widely used to investigate protein-protein interactions, receptor- and antibody-binding sites, and for selecting antibodies against a range of antigens [88]. This powerful technique has been successfully applied to identify serum biomarkers in multiple sclerosis and non-CNS disorders [89-94].

\section{Construction of a human spinal cord cDNA display library}

In order to identify novel candidate biomarkers for SCI patients, we constructed a cDNA display library from normal spinal cord tissue of 18 Caucasians. An outline of the construction of the library is shown in Figure 2. Commercially derived poly A+ RNA of human spinal cord (size range of 0.2-10 kb, Clontech, Saint-Germain-en-Laye, France) was converted to double-stranded cDNA using oligo-dT primers. The resulting cDNA inserts were directionally ligated into one of the pVI display vectors, pSPVIC, and subsequently subcloned into the pSPVIA and pSPVIB display vectors. Each of these display vectors encodes a different reading frame, ensuring that in-frame expression of the inserts occurs in one of the vectors. The generated human spinal cord (hSC)-pSPVIA, hSC-pSPVIB and hSC-pSPVIC libraries had a primary diversity of $7.42 \times 10^{6}, 1.44 \times 10^{6}$ and $2.44 \times 10^{6}$, respectively; showing a high diversity in the 3 libraries. By cloning the cDNA products into the phage genome as a C-terminal fusion of gene VI; corresponding protein products are displayed at the surface of the filamentous phage, fused to minor coat protein pVI (Figure 2). The cDNA insert lengths were determined using PCR amplification of randomly selected clones from the 3 human SC cDNA libraries. These results showed that all 3 libraries had a high variety of 
lengths ranging from 350 to 2000 basepairs (bp) and that the frequency of PCR products with a similar length was comparable in the 3 SC cDNA libraries (data not shown). To further asses the quality and diversity of the human SC cDNA libraries, sequencing of randomly selected phage clones was performed (Table 3). The nucleotide sequences were compared to GenBank databases with the basic local alignment search tool (BLAST) software of NCBI (http://blast.ncbi.nlm.nih.gov/Blast.cgi). Most of the cDNA sequences (93\%) identified genes encoding known and characterized proteins. While the majority of the genes encoded for intracellular proteins, also a large proportion of membrane-bound gene products (31\%) was found (Figure 3a). Of the intracellular proteins, 29\% (47\% of total) were specifically located to the cytoplasm, such as phosphoprotein enriched in astrocytes (PEA) 15, dysbindin (dystrobrevin binding protein 1) domain containing (DBNDD) 2 and kelch-like family member (KLHL) 42, and 25\% (41\% of total) were nuclear proteins, such as transcription factor binding to IGHM enhancer (TFE) 3, nucleoporin 43kDa (NUP43) and PR domain containing (PRDM) 5. Several of the identified gene products are found both intracellularly and at the membrane (6\%). Approximately $10 \%$ of the sequenced genes encoded extracellular proteins, that are secreted including coagulation factor $\mathrm{V}$ (F5), meteorin, glial cell differentiation regulator (METRN) and selenoprotein P plasma (SEPP) 1. Moreover, genes encoding proteins specific to the endoplasmatic reticulum (7\%), mitochondrion (3\%), golgi (3\%) and endosome (1\%) were identified, which shows that gene products of a wide variety of cellular components are represented in the libraries (Figure 3a). The identified genes were involved in a variety of general biological processes such as transcription and translation (30\%) (e.g. ribosomal protein S4, X-linked RPS4X); cell cycle (17\%) (e.g. cyclin Y $(\mathrm{CCNY}))$; signal transduction (14\%); metabolic and biosynthetic processes (11\%); transport (13\%) and cellular processes and constituents (9\%) (Figure 3b). A large proportion of the sequences encoded genes with a nervous system specific expression pattern (21\%), such as 
MBP, S100B, GFAP and erb-b2 avian erythroblastic leukemia viral oncogene homolog (ERBB) 3, indicating that the constructed libraries are a valuable source for the identification of nervous system specific biomarkers. Despite the use of normal spinal cord tissue for the construction of the cDNA libraries, genes encoding proteins involved in the immune response and response to stress (24\%) (e.g. interferon gamma receptor (IFNGR) 1) and apoptosis $(10 \%)$ (e.g. Fas apoptotic inhibitory molecule (FAIM) 2) were also present in the libraries. The constructed cDNA libraries thus allow the identification of antigenic targets of the SCIinduced secondary processes. Besides the identification of genes encoding known proteins, $7 \%$ of the sequences encoded proteins with an as yet unidentified function, which underscores the benefits of using an unbiased approach.

\section{Serological antigen selection}

The actual power of this new human spinal cord cDNA library prevails in its use to screen antibody responses in plasma of SCI patients. As CSF is difficult to obtain and it is not always feasible to obtain CSF samples from unstable SCI patients, we aim to search for biomarkers in easy accessible blood-derivatives. While inflammatory markers are hard to detect in serum and plasma, and the analysis of CSF is more relevant for SCI pathology, antibodies have several highly interesting properties which make them excellent indicators of disease. Antibodies are secreted and are therefore highly accessible and easily purified from serum and plasma (Figure 1, lower panel). Unlike most other proteins found in serum, antibodies are stable as they are not degraded by proteolysis and have a long half-live in blood. Due to their inherent amplification within the immune system, antibodies are relatively abundant and easily measured. Upon admittance to the emergency room, patients often receive fluids and blood products that might introduce a sensitivity issue as the blood of the patient and thus the concentration of the protein biomarker, is being diluted. This problem can again be circumvented when considering antibodies as biomarkers. The concentration of the 
stable and continuously produced antibodies will be elevated again when a sample is taken at a later time point. Antibodies might thus represent better biomarkers as their antigen counterparts. Moreover, since reagents bind to the constant regions of immunoglobulins, antibodies of the same class which recognize different antigens can be detected simultaneously, enabling high-throughput, faster biomarker identification and simplifying assay development. Based on these properties, antibodies are of particular interest to be studied as biomarkers and could rapidly advance the diagnosis and treatment of disease.

Pathology-specific antibodies can be selected from biofluids in an unbiased way via a procedure called serological antigen selection (SAS), a molecular approach based on cDNA phage display. In the past, SAS was performed using phage display methods that have been based on the insertion of synthetically produced peptide libraries within the phage genome. This approach has been rather unsuccessful as these libraries only allow the detection of linear epitopes, identify many target-unrelated peptides and have the drawback of identifying mimotypes, e.a. peptides forming epitopes that mimick the actual in vivo antigens. A labourintensive characterization is required for the identification of the actual in vivo target antigen of the detected antibody. Therefore, we constructed a cDNA library from human spinal cord tissue. In this way, key problems of previous methods are circumvented and our library allows rapid isolation of novel antibody targets and identifies generic antibody targets by selection on plasma samples from patients. Moreover, this new display library allows the identification of cell surface and secreted molecules as well as intracellular targets and both conformational and linear epitopes can be found. As the cDNA product display is monovalent (one cDNA product per phage particle), high-affinity interactions with antibodies are selected. An added advantage is that, using this unbiased method, multiple potential markers are studied at the same time allowing multiplexing. Using SAS on human target tissue-based cDNA display libraries, we have successfully identified novel antibody targets in many diseases such as 
colorectal cancer [92], atherosclerotic plaques [95], clinically isolated syndrome [90], multiple sclerosis (MS) [89,96] and rheumatoid arthritis [91,97]. The identification of novel antigenic targets in MS resulted in the discovery of Sperm Associated Antigen 16 (SPAG16) isoform 2. Initial characterization of SPAG16 as a candidate biomarker for MS revealed that anti-SPAG16 antibodies cannot only be found in CSF, but also in serum of MS patients. The serum levels of the anti-SPAG16 antibodies correlated with clinical characteristics of MS patients [98]. These results further emphasize the relevance of directly investigating candidate antibody biomarkers in serum of SCI patients. Moreover, we have not only demonstrated the diagnostic and prognostic value of these serum antibody biomarkers $[89,96,91]$ but also the pathogenic in vivo relevance of these novel antibodies [99].

Altogether, by constructing a cDNA library from human spinal cord tissue, SAS is an even more powerful and unbiased high-throughput method and accordingly a highly promising approach to identify novel SCI pathologically relevant antibodies and their targets. These novel antibodies might not only serve as potential SCI biomarkers, but additionally hint to new antibody-based therapeutic options for SCI pathology.

\section{Limitations}

To date, the true relevance of prognostic and severity-dependent biomarkers in SCI pathology remains inconclusive. Most evidence for SCI-associated biomarkers is derived from animal models and while they provide an exciting source of potential SCI biomarkers, these candidate markers need extensive validation. In contrast to the large number of reports on biomarkers in structural brain damage, only few studies investigated the role of biomarkers in patients with SCI. Many of the human studies performed so far have several limitations. Studies that first speculated on the biomarker potential for SCI prognosis and injury severity, typically included only few patients with one study even including only 6 patients. The small number of subjects limits the chance of finding significant correlations with certain traits or 
risks linked to SCI pathology. More recent studies that analyzed samples of over 40 patients did find significant correlations between immune mediators and neurological recovery over time [63]. Secondly, the timing of the analysis has been a substantial limitation in the current studies. Often samples collected at distinct time points after the initial trauma are pooled. Moreover, often only 1 time point is investigated which might not be the correct timing for the studied biomarker. This issue is circumvented by the set-up of longitudinal studies that will provide critical information on disease progression and the timing of pathologyassociated processes in SCI in humans, which have already proven to be different from the progression of SCI-induced processes in animals. In addition to including multiple time points in SCI biomarker research, a more extensive number of markers should be investigated simultaneously to allow modelling of different markers into a panel to increase sensitivity and specificity for SCI prognosis and injury severity. This indicates that there is a vast need for the application of unbiased multiplex profiling techniques. Another issue that restricts biomarker discovery in SCI patients is the enormous heterogeneity which is characteristic for the pathology. While some biomarkers in SCI show promising results, the high diversity in patient characteristics such as polytrauma and variability in lesion type, severity and recovery might limit finding significant results. Although this issue is intrinsic to the population and might seem impossible to circumvent, several considerations can be made. For example, not only the AIS scores but also MRI findings and patient characteristics such as age and the location of the lesion should be included to stratify the patients in the different groups and to find more subtle improvements in function. Additionally, as patients with a complete injury (AIS A) have a limited recovery potential, these patients should not be included when evaluating functional improvement over time. On the other hand, when searching for diagnostic biomarkers that can indicate whether a patient has a complete injury, patients with an AIS A are the prime target population that needs to be included. Well-defined patients 
which are grouped logically according to their characteristics and in compliance with the research question will reduce the number of patients needed to detect clinically useful markers.

In total, successful biomarker discovery is greatly dependent on the composition of the patient cohort as well as on sampling time and characteristics, including standardized sample collection, a well-defined patient population and accurate assays and reproducibility of the methods. Furthermore, although several candidates seem promising, independent replication studies are needed to confirm the validity and reproducibility of these markers. Therefore, collaborative efforts are needed to standardize a panel of biomarkers with high dynamic range and conduct sufficiently powered, multi-site studies.

\section{Future perspectives - towards a new generation of}

\section{biomarker research}

By considering antibodies as biomarkers, issues regarding sensitivity and stability, which are the main limitations of the currently studied candidate biomarkers, can be circumvented. Therefore, we propose SAS as an innovative strategy to identify novel antibody biomarkers in SCI patients and to investigate the contribution of antibodies and their targets in SCI pathology. This unbiased approach for antibody biomarker discovery combines the multiple benefits of stable and highly abundant antibodies and those of an unbiased approach. Moreover, multiple antibodies can be studies simultaneously, thereby allowing biochemical modelling of the candidate antibody biomarkers into a panel to identify patients at risk with a higher level of precision than a single marker. The application of such an innovative, highthroughput and unbiased strategy will complement the more traditional approaches and will significantly advance the discovery of novel SCI-associated biomarkers. 


\section{Abbreviations}

\begin{tabular}{|c|c|}
\hline APO & Apolipoprotein \\
\hline AIS & ASIA impairment scale \\
\hline ASIA & American spinal injury association \\
\hline AZGP1 & Zinc-alpha-2-glycoprotein \\
\hline CAR & Carbonic anhydrase \\
\hline $\mathrm{CNS}$ & Central nervous system \\
\hline CSF & Cerebrospinal fluid \\
\hline CXCL & $\mathrm{C}-\mathrm{X}-\mathrm{C}$ motif chemokine ligand \\
\hline GFAP & Glial fibrilar acidic protein \\
\hline GTF3C5 & General transcription factor $3 \mathrm{C}$ polypeptide 5 \\
\hline $\mathrm{Hp}$ & Haptoglobin \\
\hline $\mathrm{hSC}$ & Human spinal cord \\
\hline IGHG & Ig gamma chain $\mathrm{C}$ region \\
\hline $\mathrm{IL}$ & Interleukin \\
\hline LTC4 & Leukotriene C4 \\
\hline MBP & Myelin basic protein \\
\hline MCP-1 & Monocyte chemoattractant protein \\
\hline MMP & Matrix metalloproteinase \\
\hline MRI & Magnetic resonance imaging \\
\hline NF-L & Neurofilament light \\
\hline NSE & Neuron specific enolase \\
\hline pNF-H & Phosphoneurofilament heavy \\
\hline PRDX2 & Peroxiredoxin-2 \\
\hline S100B & S100 protein B \\
\hline
\end{tabular}


SAS Serological antigen selection

SBDP $\quad \alpha$-II spectrin breakdown product

SC Spinal cord

SCI Spinal cord injury

SDF-1 Stomal derived factor-1

TBI Traumatic brain injury

TNF Tumor necrosis factor

UCH-L1 Ubiquitin carboxy-terminal hydrolase L1 


\section{Tables}

Table 1: Structural and functional biomarkers in human SCI

\begin{tabular}{|c|c|c|c|c|c|}
\hline Marker & Function & Cellular source & Biofluid & Evidence & References \\
\hline $\begin{array}{l}\text { Neuron } \\
\text { specific } \\
\text { enolase } \\
\text { (NSE) }\end{array}$ & $\begin{array}{l}\text { Glycolytic } \\
\text { neuronal } \\
\text { enzyme }\end{array}$ & Neurons & $\begin{array}{l}\text { CSF } \\
\text { Serum }\end{array}$ & $\begin{array}{l}\text { CSF levels of NSE are increased in SCI patients } \\
* \text { CSF levels correlated with baseline neurological } \\
\text { impairment } \\
* \text { Serum levels are increased during the first } 48 \mathrm{~h} \\
\text { after injury } \\
* \text { Serum NSE levels in patients with vertebral } \\
\text { spine fractures were not different from controls }\end{array}$ & "[19,20,18] \\
\hline Tau & $\begin{array}{l}\text { Microtubule } \\
\text { associated } \\
\text { protein }\end{array}$ & Neurons (axons) & $\mathrm{CSF}$ & $\begin{array}{l}\text { * CSF Tau levels were increased in a severity- } \\
\text { dependent manner } \\
* \text { CSF Tau levels correlated with severity of injury } \\
\text { (measured at } 24 \mathrm{~h} \text { ) } \\
* \text { CSF Tau levels were not increased in patients } \\
\text { with post-operative spinal cord ischemia and } \\
\text { paraperesis }\end{array}$ & {$[22,23]$} \\
\hline $\begin{array}{l}\text { Neuro- } \\
\text { filaments } \\
(\mathrm{NFs})\end{array}$ & $\begin{array}{l}\text { Components } \\
\text { of } \\
\text { cytoskeleton } \\
\text { (light, } \\
\text { medium and } \\
\text { heavy NFs) }\end{array}$ & Neurons & $\begin{array}{l}\text { Plasma } \\
\text { Serum } \\
\text { CSF }\end{array}$ & $\begin{array}{l}\text { * Plasma phospho-NF-H levels are elevated } \\
* \text { Phospho-NF-H is elevated to a greater extend in } \\
\text { motor complete compared to motor incomplete } \\
\text { SCI patients } \\
* \text { NF-H concentration in the CSF is also increased } \\
\text { in motor complete vs motor incomplete patients } \\
* \text { Serum and CSF NF-L levels are increased in } \\
\text { SCI patients } \\
* \text { Serum NF-L increased over time and correlated } \\
\text { with AIS scores at baseline and months after } \\
\text { injury }\end{array}$ & $\begin{array}{l}{[25,18,26,2} \\
7]\end{array}$ \\
\hline S100B & $\begin{array}{l}\text { Calcium- } \\
\text { binding } \\
\text { protein with } \\
\text { neurotrophic } \\
\text { activity }\end{array}$ & $\begin{array}{l}\text { Astrocytes and } \\
\text { Schwann cells }\end{array}$ & $\begin{array}{l}\text { Serum } \\
\text { CSF }\end{array}$ & $\begin{array}{l}\text { * Serum and CSF levels are elevated in SCI } \\
\text { patients } \\
* \text { CSF S100B levels are higher in motor complete } \\
\text { vs motor incomplete SCI patients } \\
\text { * Serum levels are higher in patients with } \\
\text { vertebral fractures with neurological deficits } \\
\text { compared to those without deficits } \\
\text { * In patients with epidural empyema or spinal } \\
\text { metastasis increased serum levels of S100B had } \\
\text { unfavorable motor outcome } \\
\text { * Elevated serum levels of S100B are seen in } \\
\text { patients with spondylotic cervical myelopathy } \\
\text { with complicated course of post-operative } \\
\text { deterioration }\end{array}$ & $\begin{array}{l}100,31,22, \\
18,29,30,2 \\
8,20]\end{array}$ \\
\hline $\begin{array}{l}\text { Glial } \\
\text { fibrillary } \\
\text { acidic } \\
\text { protein } \\
\text { (GFAP) }\end{array}$ & $\begin{array}{l}\text { Intermediate } \\
\text { filament of } \\
\text { cytoskeleton }\end{array}$ & Astrocytes & $\begin{array}{l}\text { CSF } \\
\text { Serum }\end{array}$ & $\begin{array}{l}\text { * Elevated levels in CSF and serum of SCI } \\
\text { patients } \\
* \text { CSF levels measured at } 24 \mathrm{~h} \text { correlated with } \\
\text { injury severity } \\
\text { * In ischemic SCI, elevated levels of CSF GFAP } \\
\text { correlated with injury severity and prognosis } \\
* \text { GFAP breakdown products were found in serum } \\
\text { of SCI patients }\end{array}$ & $\begin{array}{l}{[27,22,19,1} \\
3]\end{array}$ \\
\hline $\begin{array}{l}\text { Myelin basic } \\
\text { protein } \\
\text { (MBP) }\end{array}$ & $\begin{array}{l}\text { Constituent } \\
\text { of the myelin } \\
\text { sheath }\end{array}$ & Oligodendrocytes & $\mathrm{CSF}$ & $\begin{array}{l}* \text { Retrospective study identified higher CSF } \\
\text { concentrations in patients with tropical spastic } \\
\text { paraparesis }\end{array}$ & [33] \\
\hline $\begin{array}{l}\alpha \text {-II spectrin } \\
\text { breakdown } \\
\text { products } \\
\text { (SBDPs) }\end{array}$ & & Neurons & Serum & $\begin{array}{l}\text { * Found in spinal cord after injury } \\
* \text { Elevated in a rat SCI model } \\
* \text { Elevated in serum of a SCI patient } 2 \text { days after } \\
\text { injury }\end{array}$ & {$[13,46,47]$} \\
\hline $\begin{array}{l}\text { Ubiquitin } \\
\text { carboxy- } \\
\text { terminal } \\
\text { hydrolase L1 } \\
\text { (UCH-L1) }\end{array}$ & & Neurons & Serum & $\begin{array}{l}* \text { Elevated in a rat SCI model } \\
* \text { Elevated in serum of a SCI patient } 2 \text { days after } \\
\text { injury }\end{array}$ & {$[13,39]$} \\
\hline
\end{tabular}


Table 2: Inflammation-related biomarkers in human SCI

\begin{tabular}{|c|c|c|c|c|}
\hline Marker & Function & Biofluid & Evidence & Reference \\
\hline $\begin{array}{l}\text { Interleukin } 6 \\
\text { (IL-6) }\end{array}$ & $\begin{array}{l}\text { Pleiotropic pro- } \\
\text { inflammatory } \\
\text { cytokine }\end{array}$ & $\begin{array}{l}\text { CSF } \\
\text { Serum }\end{array}$ & $\begin{array}{l}\text { * Early post-injury elevation in CSF } \\
\text { * At } 24 \text { h post-injury CSF IL-6 levels correlated with injury } \\
\text { severity } \\
\text { * Serum IL-6 was found elevated in serum, although this } \\
\text { could not be confirmed by others } \\
\text { * Serum IL-6 was increased in SCI patients with AIS A } \\
\text { compared to other the AIS subgroups }\end{array}$ & {$[66,22,68]$} \\
\hline $\begin{array}{l}\text { Interleukin } 8 \\
\text { (IL-8) }\end{array}$ & $\begin{array}{l}\text { Pleiotropic pro- } \\
\text { inflammatory } \\
\text { cytokine }\end{array}$ & $\begin{array}{l}\text { CSF } \\
\text { Serum }\end{array}$ & $\begin{array}{l}\text { * Early post-injury elevation in CSF } \\
* \text { At } 24 \text { h post-injury IL-8 CSF levels correlated with injury } \\
\text { severity } \\
\text { * Serum IL-8 was increased in SCI patients with AIS A } \\
\text { compared to other the AIS subgroups }\end{array}$ & {$[22,68]$} \\
\hline $\begin{array}{l}\text { Monocyte } \\
\text { chemoattractan } \\
\text { t protein-1 } \\
(\mathrm{MCP}-1)\end{array}$ & $\begin{array}{l}\text { Chemokine; } \\
\text { Also known as } \\
\text { CCL2 }\end{array}$ & $\begin{array}{l}\text { CSF } \\
\text { Serum }\end{array}$ & $\begin{array}{l}* \text { MCP-1 levels were increased in CSF in patients with } \\
\text { complete and incomplete SCI (peak at } 24 \text { to } 36 \mathrm{~h} \text { post injury) } \\
* \text { Early post-injury elevation in CSF } \\
* \text { At } 24 \text { h post-injury MCP-1 CSF levels correlated with } \\
\text { injury severity. }\end{array}$ & {$[58,22]$} \\
\hline $\begin{array}{l}\text { Interleukin } 1 \\
\text { beta }(\mathrm{IL}-1 \beta)\end{array}$ & $\begin{array}{l}\text { Pleiotropic pro- } \\
\text { inflammatory } \\
\text { cytokine }\end{array}$ & $\begin{array}{l}\text { CSF } \\
\text { Serum }\end{array}$ & 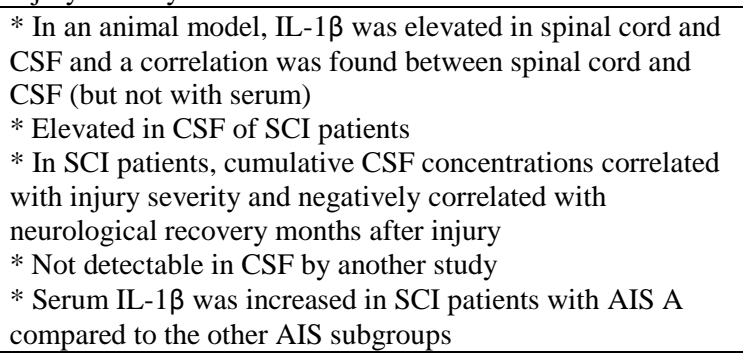 & $\begin{array}{l}{[56,59,22,} \\
58,68]\end{array}$ \\
\hline $\begin{array}{l}\text { Matrix } \\
\text { metallo- } \\
\text { proteinase-9 } \\
\text { (MMP-9) }\end{array}$ & Enzyme, protease & Serum & $\begin{array}{l}\text { * In SCI patients, cumulative CSF concentrations correlated } \\
\text { with injury severity }\end{array}$ & [59] \\
\hline $\begin{array}{l}\text { C-X-C motif } \\
\text { chemokine } \\
(\mathrm{CXCL})-10\end{array}$ & Chemokine & $\begin{array}{l}\text { CSF } \\
\text { Serum }\end{array}$ & $\begin{array}{l}* \text { Early post-injury elevation in CSF } \\
* \text { Cumulative CSF concentrations correlated negatively with } \\
\text { neurological recovery at } 12 \text { months }\end{array}$ & {$[58,68,12]$} \\
\hline $\begin{array}{l}\text { Eicosanoids } \\
\text { (LTC4) }\end{array}$ & $\begin{array}{l}\text { Signaling } \\
\text { molecules }\end{array}$ & CSF & $\begin{array}{l}\text { * Increased in CSF of SCI patients } \\
\text { * LTC4 significantly increased in CSF in complete vs } \\
\text { incomplete injury }\end{array}$ & {$[60]$} \\
\hline IL-10 & $\begin{array}{l}\text { Anti-inflammatory } \\
\text { cytokine }\end{array}$ & Serum & $\begin{array}{l}\text { * Serum IL-10 was increased in SCI patients with AIS A } \\
\text { compared to the other AIS subgroups }\end{array}$ & {$[59,68]$} \\
\hline $\begin{array}{l}\text { Tumor } \\
\text { necrosis factor } \\
\text { (TNF) }\end{array}$ & $\begin{array}{l}\text { Pleiotropic pro- } \\
\text { inflammatory } \\
\text { cytokine }\end{array}$ & $\begin{array}{l}\text { CSF } \\
\text { Serum }\end{array}$ & $\begin{array}{l}\text { * In an animal model, TNF was elevated in spinal cord and } \\
\text { CSF and a correlation was found between spinal cord and } \\
\text { CSF (but not with serum) } \\
\text { * Not detectable in CSF by another study } \\
\text { * Serum TNF was found elevated in serum, although this } \\
\text { could not be confirmed by others } \\
\text { * Elevated in serum of SCI patients with neuropathic pain } \\
\text { compared to patients without pain } \\
\text { * Serum TNF was increased in SCI patients with AIS A } \\
\text { compared to the other AIS subgroups }\end{array}$ & $\begin{array}{l}{[57,22,71,} \\
68]\end{array}$ \\
\hline
\end{tabular}

Table 3: cDNA sequences identified in new human spinal cord libraries

\begin{tabular}{lll}
\hline \hline Clone & NCBI code & cDNA identity \\
\hline SCI-1 & NM_005829 & adaptor-related protein complex 3, sigma 2 subunit (AP3S2) \\
SCI-2 & NM_003133 & signal recognition particle 9kDa (SRP9) \\
SCI-3 & NM_007110 & telomerase-associated protein 1 (TEP1) \\
SCI-4 & NM_002055 & glial fibrillary acidic protein (GFAP) \\
SCI-5 & NM_003248 & thrombospondin 4 (THBS4) \\
SCI-6 & NM_001048222 & dysbindin (dystrobrevin binding protein 1) domain containing 2 (DBNDD2) \\
SCI-7 & NM_018955 & ubiquitin B (UBB) \\
SCI-8 & NM_020782 & kelch-like family member 42 (KLHL42) \\
SCI-9 & NM_030935 & TSC22 domain family, member 4 (TSC22D4) \\
SCI-10 & NM_005028 & phosphatidylinositol-5-phosphate 4-kinase, type II, alpha (PIP4K2A) \\
SCI-11 & NM_198887 & nucleoporin 43kDa (NUP43) \\
SCI-12 & NM_001397 & endothelin converting enzyme 1 (ECE1) \\
SCI-13 & NM_031942 & cell division cycle associated 7 (CDCA7)
\end{tabular}




\begin{tabular}{|c|c|c|}
\hline SCI-14 & NM_003118 & secreted protein, acidic, cysteine-rich (osteonectin) (SPARC) \\
\hline SCI-15 & NM_018699 & PR domain containing 5 (PRDM5) \\
\hline SCI-16 & NM_014478 & calcitonin gene-related peptide-receptor component (CRCP) \\
\hline SCI-17 & NM_001012279 & SOGA family member 3 (SOGA3) \\
\hline SCI-18 & NM_024042 & meteorin, glial cell differentiation regulator (METRN) \\
\hline SCI-19 & NM_001278322 & myelin-associated oligodendrocyte basic protein (MOBP) \\
\hline SCI-20 & NM_001292016 & TNFAIP3 interacting protein 2 (TNIP2) \\
\hline SCI-21 & NM_001025101 & myelin basic protein (MBP) \\
\hline SCI-22 & NM_020466 & LYR motif containing 2 (LYRM2) \\
\hline SCI-23 & NM_003295 & tumor protein, translationally-controlled 1 (TPT1) \\
\hline SCI-24 & NM_003768 & phosphoprotein enriched in astrocytes 15 (PEA15) \\
\hline SCI-25 & NM_005557 & keratin 16, type I (KRT16) \\
\hline SCI-26 & NM_001010 & ribosomal protein S6 (RPS6) \\
\hline SCI-27 & NM_201429 & reticulon $3(\mathrm{RTN} 3)$ \\
\hline SCI-28 & NM_006521 & transcription factor binding to IGHM enhancer 3 (TFE3) \\
\hline SCI-29 & NM_173060 & calpastatin (CAST) \\
\hline SCI-30 & NM_053277 & chloride intracellular chandel 6 (CLIC6) \\
\hline SCI-31 & NM_001982 & v-erb-b2 avian erythroblastic leukemia viral oncogene homolog 3 (ERBB3) \\
\hline SCI-32 & NM_002025 & AF4/FMR2 family, member 2 (AFF2) \\
\hline SCI-33 & NM_000130 & coagulation factor $\mathrm{V}$ (proaccelerin, labile factor) (F5) \\
\hline SCI-34 & NM_014952 & bromo adjacent homology domain containing 1 (BAHD1) \\
\hline SCI-35 & NM_005348 & heat shock protein $93 \mathrm{kDa}$ alpha (cytosolic), class A member 1 (HSP90AA1) \\
\hline SCI-36 & NM_001455 & forkhead box O3 (FOXO3) \\
\hline SCI-37 & NM_014240 & LIM domain containing 1 (LIMD1) \\
\hline SCI-38 & NM_004755 & ribosomal protein S6 kinase, $90 \mathrm{kDa}$, polypeptide 5 (RPS6KA5) \\
\hline SCI-39 & NM_020337 & ankyrin repeat domain 50 (ANKRD50) \\
\hline SCI-40 & NM_032333 & family with sequence similarity 213 , member A (FAM213A) \\
\hline SCI-41 & NM_002046 & glyceraldehyde-3-phosphate dehydrogenase (GAPDH) \\
\hline SCI-42 & NM_000416 & interferon gamma receptor 1 (IFNGR1) \\
\hline SCI-43 & NM_000231 & sarcoglycan, gamma (35kDa dystrophin-associated glycoprotein) (SGCG) \\
\hline SCI-44 & NM_001431 & erythrocyte membrane protein band 4,1 like 2 (EPB41L2) \\
\hline SCI-45 & NM_000533 & proteolipid protein 1 (PLP1) \\
\hline SCI-46 & NM_016006 & abhydrolase domain containing 5 (ABHD5) \\
\hline SCI-47 & NM_006272 & S100 calcium binding protein B (S100B) \\
\hline SCI-48 & NM_001129 & AE binding protein 1 (AEBP1) \\
\hline SCI-49 & NM_145019 & family with sequence similarity $124 \mathrm{~A}$ (FAM124A) \\
\hline SCI-50 & NM_181698 & cyclin Y (CCNY) \\
\hline SCI-51 & NM_012306 & Fas apoptotic inhibitory molecule 2 (FAIM2) \\
\hline SCI-52 & NM_002954 & ribosomal protein S27a (RPS27A) \\
\hline SCI-53 & NM_004746 & discs, large (Drosophila) homolog-associated protein 1 (DLGAP1) \\
\hline SCI-54 & NM_030926 & integral membrane protein $2 \mathrm{C}$ (ITM2C) \\
\hline SCI-55 & NM_000077 & cyclin-dependent kinase inhibitor $2 \mathrm{~A}(\mathrm{CDKN} 2 \mathrm{~A})$ \\
\hline SCI-56 & NM_080591 & $\begin{array}{l}\text { prostaglandin-endoperoxide synthase } 1 \text { (prostaglandin G/H synthase and cyclooxygenase) } \\
\text { (PTGS1) }\end{array}$ \\
\hline SCI-57 & NM_002887 & arginyl-tRNA synthetase (RARS) \\
\hline SCI-58 & NM_153828 & reticulon 4 (RTN4) \\
\hline SCI-59 & NM_001007 & ribosomal protein S4, X-linked (RPS4X) \\
\hline SCI-60 & NM_002810 & proteasome (prosome, macropain) 26S subunit, non-ATPase, 4 (PSMD4) \\
\hline SCI-61 & XP_005268518 & CXXC finger protein 5 (CXXC5) \\
\hline SCI-62 & NM_138336 & myeloma overexpressed gene 2 (MYEOV2) \\
\hline SCI-63 & NM_001272061 & melanoma antigen family D, 4, 4B (MAGED4) \\
\hline SCI-64 & NM_001489 & nuclear receptor subfamily 6 , group A, member 1 (NR6A1) \\
\hline SCI-65 & NM_001807 & carboxyl ester lipase (CEL) \\
\hline SCI-66 & NM_000068 & calcium channel, voltage dependent $\mathrm{P} / \mathrm{Q}$ type alpha $1 \mathrm{~A}$ subunit (CACNA1A) \\
\hline SCI-67 & NM_020318 & integrin alpha FG-GAP repeat containing 3 (ITFG3) \\
\hline SCI-68 & NM_001207 & basic transcription factor 3 (BTF3) \\
\hline SCI-69 & NM_001677 & ATPase, $\mathrm{Na}+/ \mathrm{K}+$ transporting, beta 1 polypeptide (ATP1B1) \\
\hline SCI-70 & NM_203464 & adenylate kinase 4 (AK4) \\
\hline SCI-71 & NM_005410 & selenoprotein P, plasma, 1 (SEPP1) \\
\hline
\end{tabular}




\section{Figure legends}

\section{Figure 1 Overview of biomarker discovery approaches for SCI}

Upon injury to the spinal cord (a), CNS specific proteins are released into the CSF and bloodstream (b). The injury triggers the activation of the immune response with the release of cytokines and chemokines (c). These inflammatory mediators activate and recruit inflammatory cells to the lesion site thereby further amplifying the inflammatory response (d) which may contribute to an increased lesion in the spinal cord (e). Released CNS proteins and inflammatory mediators in the CSF and bloodstream are ideal targets for biomarker discovery (lower panel). Starting from these processes, biomarker research in SCI has focused on analyzing structural and inflammatory proteins. More recently, proteomics and biochemical modelling of candidate biomarkers have been applied to advance biomarker discovery and applicability. As antibodies might represent better biomarkers than their antigen counterparts, a novel and powerful approach based on phage display and serological antigen selection can complement the more traditional approaches in the discovery of novel SCI biomarkers. The strengths and weaknesses of the different approaches for SCI biomarker discovery are listed as well.

\section{Figure 2 Construction of the human spinal cord cDNA phage display library}

Poly(A+) RNA was isolated from healthy human SC tissues (commercially obtained) and converted to doublestranded cDNA fragments which were cloned into phagemid vector pSPVIC (primary SC library). After controlling the quality of the primary SC library, cDNA inserts were isolated and subcloned into pSPVIA and pSPVIB. Cloning of the cDNA library occurred by fusion of cDNA fragments to the C-terminus of gene VI (encoding minor coat protein pVI), which resulted in 3 cDNA display libraries (SC pSPVIA/B/C) allowing expression of the cDNA fragments in three readings frames. ds, double-stranded; sc, spinal cord; GS linker, glycine/serine-linker; MCS, multiple cloning site.

\section{Figure 3 Gene ontology of the identified gene sequences}

Bar charts depict the distribution of the identified genes within the library in terms of cellular localization (A) and biological process (B). Due to the multiple cellular localizations and biological processes of some of the genes, the total percentage in each chart is greater than 100 . 


\section{References}

1. Schaefer DM, Flanders AE, Osterholm JL, Northrup BE (1992) Prognostic significance of magnetic resonance imaging in the acute phase of cervical spine injury. Journal of neurosurgery 76 (2):218-223.

2. Flanders AE, Spettell CM, Tartaglino LM, Friedman DP, Herbison GJ (1996) Forecasting motor recovery after cervical spinal cord injury: value of MR imaging. Radiology 201 (3):649-655.

3. Miyanji F, Furlan JC, Aarabi B, Arnold PM, Fehlings MG (2007) Acute cervical traumatic spinal cord injury: MR imaging findings correlated with neurologic outcome--prospective study with 100 consecutive patients. Radiology 243 (3):820-827.

4. Lammertse D, Dungan D, Dreisbach J, Falci S, Flanders A, Marino R, Schwartz E, National Institute on D, Rehabilitation (2007) Neuroimaging in traumatic spinal cord injury: an evidence-based review for clinical practice and research. The journal of spinal cord medicine 30 (3):205-214.

5. Brown PJ, Marino RJ, Herbison GJ, Ditunno JF, Jr. (1991) The 72-hour examination as a predictor of recovery in motor complete quadriplegia. Archives of physical medicine and rehabilitation 72 (8):546-548.

6. Marino RJ, Graves DE (2004) Metric properties of the ASIA motor score: subscales improve correlation with functional activities. Archives of physical medicine and rehabilitation 85 (11):1804-1810.

7. Krishna V, Andrews H, Varma A, Mintzer J, Kindy MS, Guest J (2014) Spinal cord injury: how can we improve the classification and quantification of its severity and prognosis? Journal of neurotrauma 31 (3):215-227.

8. Scholtes F, Theunissen E, Phan-Ba R, Adriaensens P, Brook G, Franzen R, Gelan J, Schoenen J, Martin D (2011) Post-mortem assessment of rat spinal cord injury and white matter sparing using inversion recovery-supported proton density magnetic resonance imaging. Spinal cord 49 (3):345-351.

9. Navarro R, Juhas S, Keshavarzi S, Juhasova J, Motlik J, Johe K, Marsala S, Scadeng M, Lazar P, Tomori Z, Schulteis G, Beattie M, Ciacci JD, Marsala M (2012) Chronic spinal compression model in minipigs: a systematic behavioral, qualitative, and quantitative neuropathological study. Journal of neurotrauma 29 (3):499-513.

10. Kochanek PM, Berger RP, Bayir H, Wagner AK, Jenkins LW, Clark RS (2008) Biomarkers of primary and evolving damage in traumatic and ischemic brain injury: diagnosis, prognosis, probing mechanisms, and therapeutic decision making. Current opinion in critical care 14 (2):135-141.

11. Pouw MH, Hosman AJ, van Middendorp JJ, Verbeek MM, Vos PE, van de Meent H (2009) Biomarkers in spinal cord injury. Spinal cord 47 (7):519-525.

12. Kwon BK, Casha S, Hurlbert RJ, Yong VW (2011) Inflammatory and structural biomarkers in acute traumatic spinal cord injury. Clinical chemistry and laboratory medicine : CCLM / FESCC 49 (3):425-433.

13. Yokobori S, Zhang Z, Moghieb A, Mondello S, Gajavelli S, Dietrich WD, Bramlett H, Hayes RL, Wang M, Wang KK, Bullock MR (2013) Acute Diagnostic Biomarkers for Spinal Cord Injury: Review of the Literature and Preliminary Research Report. World neurosurgery. 14. Bandyopadhyay S, Hennes H, Gorelick MH, Wells RG, Walsh-Kelly CM (2005) Serum neuron-specific enolase as a predictor of short-term outcome in children with closed traumatic brain injury. Academic emergency medicine : official journal of the Society for Academic Emergency Medicine 12 (8):732-738. 
15. Loy DN, Sroufe AE, Pelt JL, Burke DA, Cao QL, Talbott JF, Whittemore SR (2005) Serum biomarkers for experimental acute spinal cord injury: rapid elevation of neuronspecific enolase and S-100beta. Neurosurgery 56 (2):391-397; discussion 391-397.

16. Nagy G, Dzsinich C, Selmeci L, Sepa G, Dzsinich M, Kekesi V, Juhasz-Nagy A (2002) Biochemical alterations in cerebrospinal fluid during thoracoabdominal aortic cross-clamping in dogs. Annals of vascular surgery 16 (4):436-441.

17. Cao F, Yang XF, Liu WG, Hu WW, Li G, Zheng XJ, Shen F, Zhao XQ, Lv ST (2008) Elevation of neuron-specific enolase and S-100beta protein level in experimental acute spinal cord injury. Journal of clinical neuroscience : official journal of the Neurosurgical Society of Australasia 15 (5):541-544.

18. Pouw MH, Kwon BK, Verbeek MM, Vos PE, van Kampen A, Fisher CG, Street J, Paquette SJ, Dvorak MF, Boyd MC, Hosman AJ, van de Meent H (2014) Structural biomarkers in the cerebrospinal fluid within $24 \mathrm{~h}$ after a traumatic spinal cord injury: a descriptive analysis of 16 subjects. Spinal cord 52 (6):428-433.

19. Ahadi R, Khodagholi F, Daneshi A, Vafaei A, Mafi AA, Jorjani M (2015) Diagnostic Value of Serum Levels of GFAP, pNF-H, and NSE Compared With Clinical Findings in Severity Assessment of Human Traumatic Spinal Cord Injury. Spine 40 (14):E823-830.

20. Wolf H, Krall C, Pajenda G, Leitgeb J, Bukaty AJ, Hajdu S, Sarahrudi K (2014) Alterations of the biomarker S-100B and NSE in patients with acute vertebral spine fractures. The spine journal : official journal of the North American Spine Society 14 (12):2918-2922.

21. Kulbe JR, Geddes JW (2015) Current status of fluid biomarkers in mild traumatic brain injury. Experimental neurology.

22. Kwon BK, Stammers AM, Belanger LM, Bernardo A, Chan D, Bishop CM, Slobogean GP, Zhang H, Umedaly H, Giffin M, Street J, Boyd MC, Paquette SJ, Fisher CG, Dvorak MF (2010) Cerebrospinal fluid inflammatory cytokines and biomarkers of injury severity in acute human spinal cord injury. Journal of neurotrauma 27 (4):669-682.

23. Shiiya N, Kunihara T, Miyatake T, Matsuzaki K, Yasuda K (2004) Tau protein in the cerebrospinal fluid is a marker of brain injury after aortic surgery. The Annals of thoracic surgery 77 (6):2034-2038.

24. Jafari SS, Maxwell WL, Neilson M, Graham DI (1997) Axonal cytoskeletal changes after non-disruptive axonal injury. Journal of neurocytology 26 (4):207-221.

25. Hayakawa K, Okazaki R, Ishii K, Ueno T, Izawa N, Tanaka Y, Toyooka S, Matsuoka N, Morioka K, Ohori Y, Nakamura K, Akai M, Tobimatsu Y, Hamabe Y, Ogata T (2012) Phosphorylated neurofilament subunit NF-H as a biomarker for evaluating the severity of spinal cord injury patients, a pilot study. Spinal cord 50 (7):493-496.

26. Kuhle J, Gaiottino J, Leppert D, Petzold A, Bestwick JP, Malaspina A, Lu CH, Dobson R, Disanto G, Norgren N, Nissim A, Kappos L, Hurlbert J, Yong VW, Giovannoni G, Casha S (2015) Serum neurofilament light chain is a biomarker of human spinal cord injury severity and outcome. Journal of neurology, neurosurgery, and psychiatry 86 (3):273-279.

27. Guez M, Hildingsson C, Rosengren L, Karlsson K, Toolanen G (2003) Nervous tissue damage markers in cerebrospinal fluid after cervical spine injuries and whiplash trauma. Journal of neurotrauma 20 (9):853-858.

28. Lee SJ, Kim CW, Lee KJ, Choe JW, Kim SE, Oh JH, Park YS (2010) Elevated serum S100B levels in acute spinal fracture without head injury. Emergency medicine journal : EMJ 27 (3):209-212.

29. Marquardt G, Setzer M, Seifert V (2004) Protein S-100b as serum marker for prediction of functional outcome in metastatic spinal cord compression. Acta neurochirurgica 146 (5):449-452.

30. Marquardt G, Setzer M, Seifert V (2004) Protein S-100b for individual prediction of functional outcome in spinal epidural empyema. Spine 29 (1):59-62. 
31. Marquardt G, Setzer M, Szelenyi A, Seifert V, Gerlach R (2009) Significance of serial S100b and NSE serum measurements in surgically treated patients with spondylotic cervical myelopathy. Acta neurochirurgica 151 (11):1439-1443.

32. Zhang B, Huang Y, Su Z, Wang S, Wang S, Wang J, Wang A, Lai X (2011) Neurological, functional, and biomechanical characteristics after high-velocity behind armor blunt trauma of the spine. The Journal of trauma 71 (6):1680-1688.

33. Ohta M, Ohta K, Nishimura M, Saida T (2002) Detection of myelin basic protein in cerebrospinal fluid and serum from patients with HTLV-1-associated myelopathy/tropical spastic paraparesis. Annals of clinical biochemistry 39 (Pt 6):603-605.

34. Lincoln S, Vaughan J, Wood N, Baker M, Adamson J, Gwinn-Hardy K, Lynch T, Hardy J, Farrer M (1999) Low frequency of pathogenic mutations in the ubiquitin carboxy-terminal hydrolase gene in familial Parkinson's disease. Neuroreport 10 (2):427-429.

35. Zetterberg M, Sjolander A, von Otter M, Palmer MS, Landgren S, Minthon L, Wallin A, Andreasen N, Blennow K, Zetterberg H (2010) Ubiquitin carboxy-terminal hydrolase L1 (UCHL1) S18Y polymorphism in Alzheimer's disease. Molecular neurodegeneration 5:11.

36. Kobeissy FH, Ottens AK, Zhang Z, Liu MC, Denslow ND, Dave JR, Tortella FC, Hayes RL, Wang KK (2006) Novel differential neuroproteomics analysis of traumatic brain injury in rats. Molecular \& cellular proteomics : MCP 5 (10):1887-1898.

37. Papa L, Akinyi L, Liu MC, Pineda JA, Tepas JJ, 3rd, Oli MW, Zheng W, Robinson G, Robicsek SA, Gabrielli A, Heaton SC, Hannay HJ, Demery JA, Brophy GM, Layon J, Robertson CS, Hayes RL, Wang KK (2010) Ubiquitin C-terminal hydrolase is a novel biomarker in humans for severe traumatic brain injury. Critical care medicine 38 (1):138-144. 38. Mondello S, Linnet A, Buki A, Robicsek S, Gabrielli A, Tepas J, Papa L, Brophy GM, Tortella F, Hayes RL, Wang KK (2012) Clinical utility of serum levels of ubiquitin Cterminal hydrolase as a biomarker for severe traumatic brain injury. Neurosurgery 70 (3):666675.

39. Ding Q, Wu Z, Guo Y, Zhao C, Jia Y, Kong F, Chen B, Wang H, Xiong S, Que H, Jing S, Liu S (2006) Proteome analysis of up-regulated proteins in the rat spinal cord induced by transection injury. Proteomics 6 (2):505-518.

40. Ringger NC, O'Steen BE, Brabham JG, Silver X, Pineda J, Wang KK, Hayes RL, Papa L (2004) A novel marker for traumatic brain injury: CSF alphaII-spectrin breakdown product levels. Journal of neurotrauma 21 (10):1443-1456.

41. Mondello S, Robicsek SA, Gabrielli A, Brophy GM, Papa L, Tepas J, Robertson C, Buki A, Scharf D, Jixiang M, Akinyi L, Muller U, Wang KK, Hayes RL (2010) alphaII-spectrin breakdown products (SBDPs): diagnosis and outcome in severe traumatic brain injury patients. Journal of neurotrauma 27 (7):1203-1213.

42. Pineda JA, Lewis SB, Valadka AB, Papa L, Hannay HJ, Heaton SC, Demery JA, Liu MC, Aikman JM, Akle V, Brophy GM, Tepas JJ, Wang KK, Robertson CS, Hayes RL (2007) Clinical significance of alphaII-spectrin breakdown products in cerebrospinal fluid after severe traumatic brain injury. Journal of neurotrauma 24 (2):354-366.

43. Cardali S, Maugeri R (2006) Detection of alphaII-spectrin and breakdown products in humans after severe traumatic brain injury. Journal of neurosurgical sciences 50 (2):25-31.

44. Pike BR, Zhao X, Newcomb JK, Posmantur RM, Wang KK, Hayes RL (1998) Regional calpain and caspase-3 proteolysis of alpha-spectrin after traumatic brain injury. Neuroreport 9 (11):2437-2442.

45. Farkas O, Polgar B, Szekeres-Bartho J, Doczi T, Povlishock JT, Buki A (2005) Spectrin breakdown products in the cerebrospinal fluid in severe head injury--preliminary observations. Acta neurochirurgica 147 (8):855-861. 
46. Schumacher PA, Eubanks JH, Fehlings MG (1999) Increased calpain I-mediated proteolysis, and preferential loss of dephosphorylated NF200, following traumatic spinal cord injury. Neuroscience 91 (2):733-744.

47. Springer JE, Azbill RD, Kennedy SE, George J, Geddes JW (1997) Rapid calpain I activation and cytoskeletal protein degradation following traumatic spinal cord injury: attenuation with riluzole pretreatment. Journal of neurochemistry 69 (4):1592-1600.

48. Yang Z, Wang KK (2015) Glial fibrillary acidic protein: from intermediate filament assembly and gliosis to neurobiomarker. Trends in neurosciences 38 (6):364-374.

49. Zhang Z, Zoltewicz JS, Mondello S, Newsom KJ, Yang Z, Yang B, Kobeissy F, Guingab J, Glushakova O, Robicsek S, Heaton S, Buki A, Hannay J, Gold MS, Rubenstein R, Lu XC, Dave JR, Schmid K, Tortella F, Robertson CS, Wang KK (2014) Human traumatic brain injury induces autoantibody response against glial fibrillary acidic protein and its breakdown products. PloS one 9 (3):e92698.

50. Papa L, Lewis LM, Falk JL, Zhang Z, Silvestri S, Giordano P, Brophy GM, Demery JA, Dixit NK, Ferguson I, Liu MC, Mo J, Akinyi L, Schmid K, Mondello S, Robertson CS, Tortella FC, Hayes RL, Wang KK (2012) Elevated levels of serum glial fibrillary acidic protein breakdown products in mild and moderate traumatic brain injury are associated with intracranial lesions and neurosurgical intervention. Annals of emergency medicine 59 (6):471483.

51. McMahon PJ, Panczykowski DM, Yue JK, Puccio AM, Inoue T, Sorani MD, Lingsma HF, Maas AI, Valadka AB, Yuh EL, Mukherjee P, Manley GT, Okonkwo DO, Casey SS, Cheong M, Cooper SR, Dams-O'Connor K, Gordon WA, Hricik AJ, Lawless K, Menon D, Schnyer DM, Vassar MJ (2015) Measurement of the glial fibrillary acidic protein and its breakdown products GFAP-BDP biomarker for the detection of traumatic brain injury compared to computed tomography and magnetic resonance imaging. Journal of neurotrauma $32(8): 527-533$.

52. Johnsson P, Blomquist S, Luhrs C, Malmkvist G, Alling C, Solem JO, Stahl E (2000) Neuron-specific enolase increases in plasma during and immediately after extracorporeal circulation. The Annals of thoracic surgery 69 (3):750-754.

53. Yang L, Jones NR, Blumbergs PC, Van Den Heuvel C, Moore EJ, Manavis J, Sarvestani GT, Ghabriel MN (2005) Severity-dependent expression of pro-inflammatory cytokines in traumatic spinal cord injury in the rat. Journal of clinical neuroscience : official journal of the Neurosurgical Society of Australasia 12 (3):276-284.

54. R L (2003) Considerations for the Use of Blood Plasma and Serum for Proteomic Analysis. The Internet Journal of Genomics and Proteomics Volume 1 (Number 2).

55. Good DM TV, Novak J, Bascands JL, Schanstra JP, Coon JJ, Dominiczak A, Mishak H (2007) Body fluid proteomics for biomarker discovery: lessons from the past hold the key to success in the future. J Proteome Res 6 (12):4549-4555.

56. Wang CX, Olschowka JA, Wrathall JR (1997) Increase of interleukin-1beta mRNA and protein in the spinal cord following experimental traumatic injury in the rat. Brain research 759 (2):190-196.

57. Harrington JF, Messier AA, Levine A, Szmydynger-Chodobska J, Chodobski A (2005) Shedding of tumor necrosis factor type 1 receptor after experimental spinal cord injury. Journal of neurotrauma 22 (8):919-928.

58. Tsai MC, Wei CP, Lee DY, Tseng YT, Tsai MD, Shih YL, Lee YH, Chang SF, Leu SJ (2008) Inflammatory mediators of cerebrospinal fluid from patients with spinal cord injury. Surgical neurology 70 Suppl 1:S1:19-24; discussion S11:24.

59. Casha S, T. R, DP. S, McGowan D, C. S, M. S, al. e (2009) CSF inflammatory changes correlate with injury severity and recovery after human spinal cord injury. Congress of Neurological Surgeons, Annual Meeting New Orleans, LA. 
60. Nishisho T, Tonai T, Tamura Y, Ikata T (1996) Experimental and clinical studies of eicosanoids in cerebrospinal fluid after spinal cord injury. Neurosurgery 39 (5):950-956; discussion 956-957.

61. Davies AL, Hayes KC, Dekaban GA (2007) Clinical correlates of elevated serum concentrations of cytokines and autoantibodies in patients with spinal cord injury. Archives of physical medicine and rehabilitation 88 (11):1384-1393.

62. Hayes KC, Hull TC, Delaney GA, Potter PJ, Sequeira KA, Campbell K, Popovich PG (2002) Elevated serum titers of proinflammatory cytokines and CNS autoantibodies in patients with chronic spinal cord injury. Journal of neurotrauma 19 (6):753-761.

63. Moghaddam A, Child C, Bruckner T, Gerner HJ, Daniel V, Biglari B (2015) Posttraumatic inflammation as a key to neuroregeneration after traumatic spinal cord injury. International journal of molecular sciences 16 (4):7900-7916.

64. Stein A, Panjwani A, Sison C, Rosen L, Chugh R, Metz C, Bank M, Bloom O (2013) Pilot study: elevated circulating levels of the proinflammatory cytokine macrophage migration inhibitory factor in patients with chronic spinal cord injury. Archives of physical medicine and rehabilitation 94 (8):1498-1507.

65. Bank M, Stein A, Sison C, Glazer A, Jassal N, McCarthy D, Shatzer M, Hahn B, Chugh R, Davies P, Bloom O (2015) Elevated circulating levels of the pro-inflammatory cytokine macrophage migration inhibitory factor in individuals with acute spinal cord injury. Archives of physical medicine and rehabilitation 96 (4):633-644.

66. Segal JL, Gonzales E, Yousefi S, Jamshidipour L, Brunnemann SR (1997) Circulating levels of IL-2R, ICAM-1, and IL-6 in spinal cord injuries. Archives of physical medicine and rehabilitation 78 (1):44-47.

67. Frost F, Roach MJ, Kushner I, Schreiber P (2005) Inflammatory C-reactive protein and cytokine levels in asymptomatic people with chronic spinal cord injury. Archives of physical medicine and rehabilitation 86 (2):312-317.

68. Zaaqoq AM, Namas R, Almahmoud K, Azhar N, Mi Q, Zamora R, Brienza DM, Billiar TR, Vodovotz Y (2014) Inducible protein-10, a potential driver of neurally controlled interleukin-10 and morbidity in human blunt trauma. Critical care medicine 42 (6):1487-1497. 69. Liu SQ, Ma YG, Peng H, Fan L (2005) Monocyte chemoattractant protein-1 level in serum of patients with acute spinal cord injury. Chinese journal of traumatology $=$ Zhonghua chuang shang za zhi / Chinese Medical Association 8 (4):216-219.

70. Hassanshahi G, Amin M, Shunmugavel A, Vazirinejad R, Vakilian A, Sanji M, Shamsizadeh A, RafatPanah H, Poor NM, Moosavi SR, Taheri S (2013) Temporal expression profile of CXC chemokines in serum of patients with spinal cord injury. Neurochemistry international 63 (5):363-367.

71. Xu J, E X, Liu H, Li F, Cao Y, Tian J, Yan J (2015) Tumor necrosis factor-alpha is a potential diagnostic biomarker for chronic neuropathic pain after spinal cord injury. Neuroscience letters 595:30-34.

72. Mizrachi Y, Ohry A, Aviel A, Rozin R, Brooks ME, Schwartz M (1983) Systemic humoral factors participating in the course of spinal cord injury. Paraplegia 21 (5):287-293.

73. Zajarias-Fainsod D, Carrillo-Ruiz J, Mestre H, Grijalva I, Madrazo I, Ibarra A (2012) Autoreactivity against myelin basic protein in patients with chronic paraplegia. European spine journal : official publication of the European Spine Society, the European Spinal Deformity Society, and the European Section of the Cervical Spine Research Society 21 (5):964-970.

74. Zhang Y, Popovich P (2011) Roles of autoantibodies in central nervous system injury. Discovery medicine 11 (60):395-402.

75. Taranova NP, Makarov A, Amelina OA, Luchakova OS, Loboda EB, Leikin IB (1992) [The production of autoantibodies to nerve tissue glycolipid antigens in patients with 
traumatic spinal cord injuries]. Zhurnal voprosy neirokhirurgii imeni N N Burdenko (4-5):2124.

76. Jeter CB, Hergenroeder GW, Hylin MJ, Redell JB, Moore AN, Dash PK (2013) Biomarkers for the diagnosis and prognosis of mild traumatic brain injury/concussion. Journal of neurotrauma $30(8): 657-670$.

77. Diamandis EP (2004) Mass spectrometry as a diagnostic and a cancer biomarker discovery tool: opportunities and potential limitations. Molecular \& cellular proteomics : MCP 3 (4):367-378.

78. Zurbig P, Jahn H (2012) Use of proteomic methods in the analysis of human body fluids in Alzheimer research. Electrophoresis 33 (24):3617-3630.

79. Yan X, Liu J, Luo Z, Ding Q, Mao X, Yan M, Yang S, Hu X, Huang J, Luo Z (2010) Proteomic profiling of proteins in rat spinal cord induced by contusion injury. Neurochemistry international 56 (8):971-983.

80. Chen A, Sun S, Ravikumar R, Visavadiya NP, Springer JE (2013) Differential proteomic analysis of acute contusive spinal cord injury in rats using iTRAQ reagent labeling and LCMS/MS. Neurochemical research 38 (11):2247-2255.

81. Gao Q, Liang Y, Yang X, Liu G, Li X, Zhu B, Liu J, Yang M, Xia W, Dong J, Jiao J (2012) Differential protein expression in spinal cord tissue of a rabbit model of spinal cord ischemia/reperfusion injury. Neural regeneration research 7 (20):1534-1539.

82. Kang SK, So HH, Moon YS, Kim CH (2006) Proteomic analysis of injured spinal cord tissue proteins using 2-DE and MALDI-TOF MS. Proteomics 6 (9):2797-2812.

83. Chen A, McEwen ML, Sun S, Ravikumar R, Springer JE (2010) Proteomic and phosphoproteomic analyses of the soluble fraction following acute spinal cord contusion in rats. Journal of neurotrauma 27 (1):263-274.

84. Afjehi-Sadat L, Brejnikow M, Kang SU, Vishwanath V, Walder N, Herkner K, Redl H, Lubec G (2010) Differential protein levels and post-translational modifications in spinal cord injury of the rat. J Proteome Res 9 (3):1591-1597.

85. Lubieniecka JM, Streijger F, Lee JH, Stoynov N, Liu J, Mottus R, Pfeifer T, Kwon BK, Coorssen JR, Foster LJ, Grigliatti TA, Tetzlaff W (2011) Biomarkers for severity of spinal cord injury in the cerebrospinal fluid of rats. PloS one 6 (4):e19247.

86. Light M, Minor KH, DeWitt P, Jasper KH, Davies SJ (2012) Multiplex array proteomics detects increased MMP-8 in CSF after spinal cord injury. Journal of neuroinflammation 9:122.

87. Sengupta MB, Basu M, Iswarari S, Mukhopadhyay KK, Sardar KP, Acharyya B, Mohanty PK, Mukhopadhyay D (2014) CSF proteomics of secondary phase spinal cord injury in human subjects: perturbed molecular pathways post injury. PloS one 9 (10):e110885.

88. Bradbury AR (2010) The use of phage display in neurobiology. Current protocols in neuroscience / editorial board, Jacqueline N Crawley [et al] Chapter 5:Unit 512.

89. Somers V, Govarts C, Somers K, Hupperts R, Medaer R, Stinissen P (2008) Autoantibody profiling in multiple sclerosis reveals novel antigenic candidates. Journal of immunology 180 (6):3957-3963.

90. Rouwette M, Somers K, Govarts C, De Deyn PP, Hupperts R, Van Wijmeersch B, De Jong BA, Verbeek MM, Van Pesch V, Sindic C, Villar LM, Alvarez-Cermeno JC, Stinissen P, Somers V (2012) Novel cerebrospinal fluid and serum autoantibody targets for clinically isolated syndrome. Journal of neurochemistry 123 (4):568-577.

91. Somers K, Geusens P, Elewaut D, De Keyser F, Rummens JL, Coenen M, Blom M, Stinissen P, Somers V (2011) Novel autoantibody markers for early and seronegative rheumatoid arthritis. Journal of autoimmunity 36 (1):33-46.

92. Somers VA, Brandwijk RJ, Joosten B, Moerkerk PT, Arends JW, Menheere P, Pieterse WO, Claessen A, Scheper RJ, Hoogenboom HR, Hufton SE (2002) A panel of candidate 
tumor antigens in colorectal cancer revealed by the serological selection of a phage displayed cDNA expression library. Journal of immunology 169 (5):2772-2780.

93. Wang X, Zhong P, Luo PP, Wang KC (2011) Antibody engineering using phage display with a coiled-coil heterodimeric Fv antibody fragment. PloS one 6 (4):e19023.

94. Weng X, Liao Q, Li K, Li Y, Mi M, Zhong D (2012) Screening serum biomarker of knee osteoarthritis using a phage display technique. Clinical biochemistry 45 (4-5):303-308.

95. Cleutjens KB, Faber BC, Rousch M, van Doorn R, Hackeng TM, Vink C, Geusens P, ten Cate H, Waltenberger J, Tchaikovski V, Lobbes M, Somers V, Sijbers A, Black D, Kitslaar PJ, Daemen MJ (2008) Noninvasive diagnosis of ruptured peripheral atherosclerotic lesions and myocardial infarction by antibody profiling. The Journal of clinical investigation 118 (8):2979-2985.

96. Govarts C, Somers K, Hupperts R, Stinissen P, Somers V (2007) Exploring cDNA phage display for autoantibody profiling in the serum of multiple sclerosis patients: optimization of the selection procedure. Annals of the New York Academy of Sciences 1109:372-384.

97. Somers K, Stinissen P, Somers V (2009) Optimization of high-throughput autoantibody profiling for the discovery of novel antigenic targets in rheumatoid arthritis. Annals of the New York Academy of Sciences 1173:92-102.

98. De Bock L, Fraussen J, Villar LM, Alvarez-Cermeno JC, Van Wijmeersch B, Van Pesch V, Stinissen P, Somers V (2015) Anti-SPAG16 antibodies in primary progressive multiple sclerosis are associated with an elevated progression index. Eur J Neurol (accepted).

99. de Bock L, Somers K, Fraussen J, Hendriks JJ, van Horssen J, Rouwette M, Hellings N, Villar LM, Alvarez-Cermeno JC, Espino M, Hupperts R, Jongen P, Damoiseaux J, Verbeek MM, De Deyn PP, D'Hooghe M, Van Wijmeersch B, Stinissen P, Somers V (2014) Spermassociated antigen 16 is a novel target of the humoral autoimmune response in multiple sclerosis. Journal of immunology 193 (5):2147-2156.

100. Marquardt G, Setzer M, Szelenyi A, Seifert V, Gerlach R (2009) Prognostic relevance of serial S100b and NSE serum measurements in patients with spinal intradural lesions. Neurological research 31 (3):265-269. 